\title{
The Analysis of the Effectiveness of Team Type Cooperative Learning Model Tournament (TGT) Based on the Snake and Ladder Game Media in Indonesian Literature Online Material during the Covid-19 Pandemic
}

\author{
Halimah Tussadiah $^{\mathbf{1}}$, Mutia Febriyana ${ }^{2}$ \\ ${ }^{1,2}$ Universitas Muhammadiyah Sumatera Utara, Indonesia \\ tussadiahhalimah60@gmail.com,mutiafebriyana@umsu.ac.id
}

\begin{abstract}
This study aims to determine (1) the validity of the development of the cooperative learning model type team games tournament (TGT) based on snake and ladder game media which is carried out online on Indonesian Literature material for students of the Indonesian Language Education study program, FKIP UMSU ?, and (2) the effectiveness of model development. Cooperative learning type team games tournament (TGT) based on snake and ladder game media which was carried out online on Indonesian Literature material for students of the Indonesian Language Education study program, FKIP UMSU. This research is a type of development research with a 4D model, namely define, design, develop, and disseminate. Data collection techniques in this study were carried out through observation, questionnaires, and tests. The research trial was carried out in Semester IV of the Indonesian Language Education Study Program. The results of the study proved that student learning outcomes reached $100 \%$ after being given the application of the team games tournament (TGT) learning model based on the snake and ladder game media. The results of the validity test by the validator show that the use of snake and ladder game media is valid and effective in online learning.
\end{abstract}

Keywords

effectiveness cooperative learning, game media; covid-19

\section{Introduction}

The era of globalization is increasingly dynamic and affects all aspects of life. Therefore, a paradigm shift in the learning process about how a person learns and the teaching material is given to learning objectives, namely students. The 21 st Century learning curriculum refers to learner-centered learning. Therefore, the role and readiness of an educator (lecturer) is expected to be able to act creatively in creating a variety of fun learning activities for students as learners in the learning process.

Students are one of the objects / goals of education. Students are students with a critical learning ability level towards understanding the subjects that are also presented in higher education. Muhammadiyah University of North Sumatra, as the best private university in North Sumatra, in this case enforces the obligation for students as learners to take a whole series of compulsory courses in each department of their study program.

Learning is receiving knowledge, while teaching giving knowledge. In the opinion (Hanafy, 2014) "The process of behavior change can occur in a variety of conditions based on explanations from education and psychology experts while learning is an activity that 
progresses through stages and is systematic and requires good design, accurate implementation, and evaluation". Learning is an attempt by someone to facilitate the occurrence of a learning process for students. Learning can be interpreted as a process of interaction between students and teachers as educators and sources of learning in the learning environment. (Ismail, 2020)

Indonesian literature is one of the compulsory subjects for fourth semester students to study the Indonesian Language Education Study Program, FKIP UMSU. This course presents various discussions related to Indonesian literature as a part of the literature course. This course also involves students' activeness, creativity and accuracy in carrying out learning activities in class. The implementation of these learning activities is always guided by the KKNI reference curriculum so that students are directly involved in implementing learning in the classroom. However, the implementation of learning not satisfactory. This is caused by several factors, including the learning modeling that is not varied or boring. The learning process carried out in the classroom is still based on conventional learning models, in this case the lecturer still plays a major role, namely one-way learning. In addition, students also still have difficulty understanding and appreciating the values of Indonesian literature. These various things have an impact on the achievement of unsatisfactory learning outcomes.

Responding to the findings of the above problems, it is necessary to have a cooperative learning model and appropriate creative learning media to provide flexibility in interaction between lecturers and students and students and students during the teaching and learning process. Of course, positive impact interactions can give enthusiasm and mutuality to students following the learning process. This study uses a cooperative learning modelteam games tournament (TGT) based on the snake and ladder game media because the learning model paired with the learning media is a group learning model that is able to guide and direct students to solve problems independently with the work team through the use of learning media, namely the snake and ladder game. Related to this, the role of lecturers in helping students if they encounter difficulties in solving problems. Thus, the cooperative learning model and learning media developed are adjusted to the stages in the team games tournament (TGT) type of cooperative learning model based on the snake and ladder game media.

This research is expected to make it easier for students to understand the subject matter of Indonesian Literature, researchers design and develop cooperative learning models team games tournament (TGT) Snake and ladder based media game. In the eyes of Indonesian Literature, it is carried out using the stages of the cooperative learning model type team games tournament (TGT). The stages of the learning model consist of eight phases / stages of the team games tournament (TGT) type of cooperative learning model. In addition, the material eye as intended is also implemented using learning media, namely the snake and ladder game media. The implementation of learning using a cooperative learning model type team games tournament (TGT) based on snake and ladder game media is carried out in group learning tournaments to replace quizzes, where students play the snake and ladder game at the tournament table with other team members to contribute points to their team's score. A "shift position" procedure makes this game quite fair. High achieving students play with high achieving students and low achieving students play with low achievement students as well. Both have the same chance to succeed and determine the score for their group. The implementation of the team games tournament (TGT) type cooperative learning model based on snake and ladder game media adds a dimension of joy for students that is obtained from the use of games. Teammates will help each other prepare for the game by studying the activity sheets and explaining each other's problems, but when students are playing the game, teammates should not help, ensuring individual responsibility has occurred. The development of cooperative learning model type team games tournament (TGT) based on snake and ladder game media aims to make students able to understand the subject of Indonesian Literature 
properly, precisely, efficiently and pleasantly in the implementation of learning. This is in line with the opinion of Slavin (2016) that TGT consists of five components, namely: percentage in class, team, games, tournaments, and team recognition. Based on this description, researchers are interested in conducting research by finding the development of a cooperative learning model type team games tournament (TGT) based on snake and ladder game media for students of the Indonesian language education study program at FKIP UMSU. The formulation of the research problems (1) How is the validity of the development of the cooperative learning model type team games tournament (TGT) based on snake and ladder game media which is carried out online on Indonesian Literature material for students of the Indonesian Language Education study program, FKIP UMSU ?, (2) How is the effectiveness of the development cooperative learning model type team games tournament (TGT) based on snake and ladder game media which is implemented online on Indonesian Literature material for students of the Indonesian Language Education study program, FKIP UMSU ?. Meanwhile, the purpose of this research is to answer the problem formulation above. (2) How is the effectiveness of developing a cooperative learning model type team games tournament (TGT) based on snake and ladder game media which is carried out online on Indonesian Literature material for students of the Indonesian Language Education study program, FKIP UMSU? Meanwhile, the purpose of this research is to answer the problem formulation above. (2) How is the effectiveness of developing a cooperative learning model type team games tournament (TGT) based on snake and ladder game media which is carried out online on Indonesian Literature material for students of the Indonesian Language Education study program, FKIP UMSU? Meanwhile, the purpose of this research is to answer the problem formulation above.

\section{Review of Literatures}

Cooperative Learning is a learning activity in groups to work together to help each other construct concepts and solve problems. Cooperative Learning does not have to be the same from various family statuses or mindset of each other. (Shoimin in Karo et al, 2020)

Cooperative script learning is based on the concept of constructivism, in this learning there is an agreement between students about the rules in collaboration. Problems that are solved together will be concluded together, the role of the teacher is only as a facilitator who directs students to achieve learning goals. In student interaction there is agreement, discussion, expressing opinions on the main ideas of the material, reminding each other of the concluding misconceptions, making conclusions together. The learning interactions that occur are really the dominant interactions between students and students. In student activities during learning really empowered the potential of students to actualize their knowledge and skills, so it really is in accordance with the constructivist approach developed at this time. (Siahaan et al, 2020)

\section{Research Methods}

This research is a development research. In line with Sugiyono's statement (2012: 407), development research is research that is used to produce products and test the effectiveness of these products. The development of this research is the snake and ladder game media juxtaposed with the application of the Team Games Tournament (TGT) learning model. This is applied in the subject of Indonesian Literature in the fourth semester. The learning media development model uses a 4D design. The trial treatment was applied twice. Data collection techniques to determine the effectiveness and validity of the learning media through observation and questionnaires. Meanwhile, to find out student learning outcomes, tests are carried out. 


\section{Results and Discussion}

The following is a description of the results of the development and implementation of the team games tournament (TGT) learning model based on the snake and ladder game media.

\subsection{Implementation of online learning through the application of the Team Games} Tournament (TGT) Learning Model based on the snake and ladder game media

Substantially, online learning in the subject of Indonesian Literature is carried out in groups using the Team Games Tournament (TGT) learning model based on the snake and ladder game media. The learning syntax is as follows.

a. Lecturers coordinate with students joining online classes through the Zoom Meeting application,

b. Lecturers convey their perceptions and learning objectives

c. The lecturer divides students into groups / teams, each team consists of four people,

d. The lecturer provides instructions for starting the game (tournament).

e. The lecturer visually shows the snake and ladder game board, question cards, chance cards and gacok

f. The lecturer draws a card containing a question, for students who can answer correctly are allowed to roll the dice through the dice application downloaded from the Playstore.

g. The game continues until the class period ends or the winner with the highest score is found.

$\mathrm{h}$. Then the student with the highest score shifts to the tournament table (the snake and ladder board game) with a higher grade, the second place remains in place and the third shifts to the tournament table with a lower grade.

\subsection{Testing of the Snake and Ladder Game Media Validation}

The validation of the snake and ladder game media was carried out by two expertsconsisting of instructional media experts and subject instructors.

Table 1.Validation Results of Snakes and Ladders Game Media

\begin{tabular}{clcc}
\multirow{2}{*}{ No. } & \multicolumn{1}{c}{ Assessment Aspects } & \multicolumn{2}{c}{ Rating Score (Validator) } \\
\cline { 3 - 4 } & & \multicolumn{2}{c}{ Assessment criteria } \\
\cline { 2 - 3 } & & Validator 1 & Validator 2 \\
\hline 1 & Snakes and ladder game media display & Good \\
\hline 2 & $\begin{array}{l}\text { The clarity of the presentation of written numbers } \\
\text { on the snake and ladder game media }\end{array}$ & Very good & Good \\
\hline 3 & $\begin{array}{l}\text { The clarity of the image presentation in the snake } \\
\text { and ladder game media }\end{array}$ & Very good & Very good \\
\hline 4 & $\begin{array}{l}\text { The compatibility of the snake and ladder game } \\
\text { media with learning outcomes / objectives }\end{array}$ & Very good & Very good \\
\hline 5 & $\begin{array}{l}\text { The compatibility of the snake and ladder game } \\
\text { media with learning material content }\end{array}$ & Very good & Good \\
\hline & $\begin{array}{l}\text { Presentation of instructions for using the snake and } \\
\text { ladder game media through the TGT learning } \\
\text { model }\end{array}$ & Very good & Very good \\
\hline 7 & $\begin{array}{l}\text { The appropriateness of the snake and ladder game } \\
\text { media with the snake and ladder game concept }\end{array}$ & Very good & Very good \\
\hline $\begin{array}{l}\text { Average of the validator1 and validator2 assessment } \\
\text { criteria }\end{array}$ & Very good & Very good \\
Source: Processed data & &
\end{tabular}


The results of the snake and ladder game media validation presented in table 1 above show that the snake and ladder game media applied in the developed Team Games Tournament (TGT) learning model is valid (valid) to be implemented in online learning. The development of the snake and ladder game media used as a learning medium refers to the principles of evaluating learning media. Sadiman, et al (1984: 92) explain that there are principles that must be considered in learning media including (1) instructional media must be in accordance with the learning objectives, (2) vocabulary, (3) conformity to the content of the material, (4) conformity with various types of students (characteristics of students), and (5) image or visual quality in other words.

\subsection{Re-Technique Reliability Testing of Snake and Ladder Media Game}

Reliability testing is done through re-engineering external reliability testing in order to try out the instrument or product that was developed several times and then the results are recorded. This is in line with Arikunto (2010: 222) who explains that the reliability test of the snake and ladder game media was carried out in the trial which was applied to 15 students. The results showed that there were 15 students with fast abilities, 7 students with moderate abilities, and 3 students with slow abilities. In this case, a questionnaire was given to students to determine the effectiveness of the snake and ladder game media in the team games tournament (TGT) learning model application. The following are the results of the reliability test mentioned above.

Table 2. Reliability Testing Results of Snake and Ladders Game Media

\begin{tabular}{cccc} 
No & \multicolumn{1}{c}{ Information } & \multicolumn{2}{c}{ Student Answer Criteria } \\
\cline { 3 - 4 } - & $\begin{array}{l}\text { Frequency } \\
\text { Is the snake and ladder game media provided by }\end{array}$ & $100 \%$ \\
1 & $\begin{array}{l}\text { the lecturer that you can easily use in learning } \\
\text { Indonesian Literature material }\end{array}$ & 25 & $100 \%$ \\
\hline $\begin{array}{l}\text { Do you understand well the content and content } \\
\text { presented in the snake and ladder game by the } \\
\text { teaching lecturer }\end{array}$ & 25 & $100 \%$ \\
\hline 3 & $\begin{array}{l}\text { Is the image presentation on the snake and ladder } \\
\text { game media clearly visible }\end{array}$ & 25 & $100 \%$ \\
\hline $4 \quad \begin{array}{l}\text { Is the number presentation in the snake and ladder } \\
\text { game media clearly visible }\end{array}$ & 25 & $100 \%$ \\
\hline 5 & $\begin{array}{l}\text { Does the visualization presentation in the snake } \\
\text { and ladder game media look interesting }\end{array}$ & 25 & $\mathbf{1 0 0 \%}$ \\
\hline Average student answer criteria (\%) & &
\end{tabular}

Source: Processed data

The results of testing the reliability of the snake and ladder game media based on table 2 show that on average the students gave a $100 \%$ response which stated that there were no obstacles to the application of the snake and ladder game media in the team games tournament (TGT) learning model application. In other words, the snake and ladder game media in the team games tournament (TGT) learning model application is effectively used by students and lecturers in implementing online learning activities. 
4.4 The results of the development of the cooperative learning model type team games tournament (TGT) based on snake and ladder game media which was carried out online on Indonesian Literature material for students of the Indonesian Language Education Study Program, FKIP UMSU

The cooperative learning model type team games tournament (TGT) based on snake and ladder game media which is carried out online on Indonesian Literature material for students of the Indonesian Language Education study program, FKIP UMSU. The snake and ladder game media presentation consists of 50 columns / boxes, mummies, 100 question cards, 10 chance cards and dice applications that are downloaded by students through their respective android aps.store.

The development design in this study refers to the 4D design which consists of the stages of define, design, develop, and disseminate. The flow includes analysis of learning objectives, content analysis of learning material content, analysis of student needs, testing of learning media and reporting. The stage of developing learning media for the snake and ladder game in this study was carried out according to the rules of the stage of media development based on expert opinion. In addition, the analysis of learning objectives is in accordance with the content standards in the KKNI curriculum which are implemented in learning and the elaboration of course material achievements through content analysis of Indonesian Literature sub-material in Semester IV Indonesian Language Education Study Program FKIP UMSU. This is in line with the analysis of student needs, namely the special impact on the learning outcomes of the fourth semester students of the Indonesian Language Education Study Program, FKIP UMSU. The following is a presentation of student learning outcomes through usecooperative learning model type team games tournament (TGT) based on snake and ladder game media which is conducted online on Indonesian Literature material for students of the fourth semester of the Indonesian Language Education study program, FKIP UMSU.

Table 3. Student Learning Outcomes in Implementation Indonesian Literature Subjects Learning

\begin{tabular}{|c|c|c|}
\hline $\begin{array}{c}\text { Number of } \\
\text { Students }\end{array}$ & $\begin{array}{c}\text { Before applying the } \\
\text { TGT model based on } \\
\text { the Snake and Ladder } \\
\text { Game Media } \\
\text { (Percentage of KKM } \\
\text { Achievement) }\end{array}$ & $\begin{array}{c}\text { Before applying the } \\
\text { TGT model based on } \\
\text { the Snake and Ladder } \\
\text { Game Media } \\
\text { (Percentage of KKM } \\
\text { Achievement) }\end{array}$ \\
\hline 25 Students & $48 \%$ & $100 \%$ \\
\hline
\end{tabular}

Source: Processed data

Based on table 3 above shows student learning outcomes before and after use cooperative learning model type team games tournament (TGT) based on snake and ladder game media which is implemented online on Indonesian Literature material. The learning outcomes before using the model and game media mentioned above have not fully reached the KKM, namely $48 \%$ of students who have scores above the KKM, while the percentage of student learning completeness increases after the application of the TGT model based on the snake and ladder game media, which reaches $100 \%$. 


\section{Conclusion}

The use of models juxtaposed with game media as teaching media in learning activities has been proven to be able to facilitate students in solving various challenges and demands for successful learning. One of them is through the use of the team games tournament (TGT) type cooperative learning model based on snake and ladder game media which is carried out online on Indonesian Literature material. In this case, the development of the snake and ladder game media that is applied along with the use of the team games tournament (TGT) learning model can be concluded to obtain an adequate validity value based on the results of validation by the validator.

\section{Suggestion}

The implementation results mentioned above also influence the student learning process and outcomes. Thus, it is hoped that this research can be a good solution for teachers in overcoming the various learning constraints of students, namely through the use of the team games tournament (TGT) type cooperative learning model based on the snake and ladder game media.

\section{References}

Arikunto. (2010). Prosedur Penelitian: Suatu Pendekatan Praktik. Jakarta: Rineka Cipta.

Ismail. (2020). The Application of Jigsaw Cooperative Learning Model towards the Improvement of Students' Critical Thinking Ability in Public Senior High School 15 Banda Aceh, Indonesia. Budapest International Research and Critics in Linguistics and Education (BirLE) Journal. P. 1113-1122.

Karo, R. et al. (2020). The Effect of STAD Cooperative Learning Model and Critical Thinking Ability on Learning Outcomes PPKn Grade V Students of SD Negeri 060934 Medan Johor. Budapest International Research and Critics in Linguistics and Education (BirLE) Journal. P. 871-878.

Musfiqon. (2012). Pengembangan Media Belajar Dan Sumber Belajar. Jakarta : Prestasi Pustakakarya.

Qodriah, S. L., Hartati, W., \& Karim, A. (2019). Self-leadership and career success: Motivation of college lecturers. Journal of Leadership in Organizations, 1(2), 79-95. https://doi.org/https://doi.org/10.22146/jlo.47772

Sadiman.S, et al. (1984). Media Pendidikan: Pengertian, Pengembangan dan Pemanfaatannya. Cetakan 2007. Jakarta: Raja Grafindo Persada.

Siahaan, A. et al. (2020). Implementation of Cooperative Script Learning Strategy in Historical Aspects in Islamic Education Students of SMPN 3 Pulau Rakyat Asahan District. Budapest International Research and Critics in Linguistics and Education (BirLE) Journal. P. 1564-1569.

Sugiyono. (2012). Metode Penelitian Pendidikan: Pendekatan Kuantitatif, Kualitatif dan R\&D. Bandung: Alfabeta.

Slavin, R. E. (2010). Cooperative Learning Teori, Riset dan Praktik. Bandung: Nusa Media. 